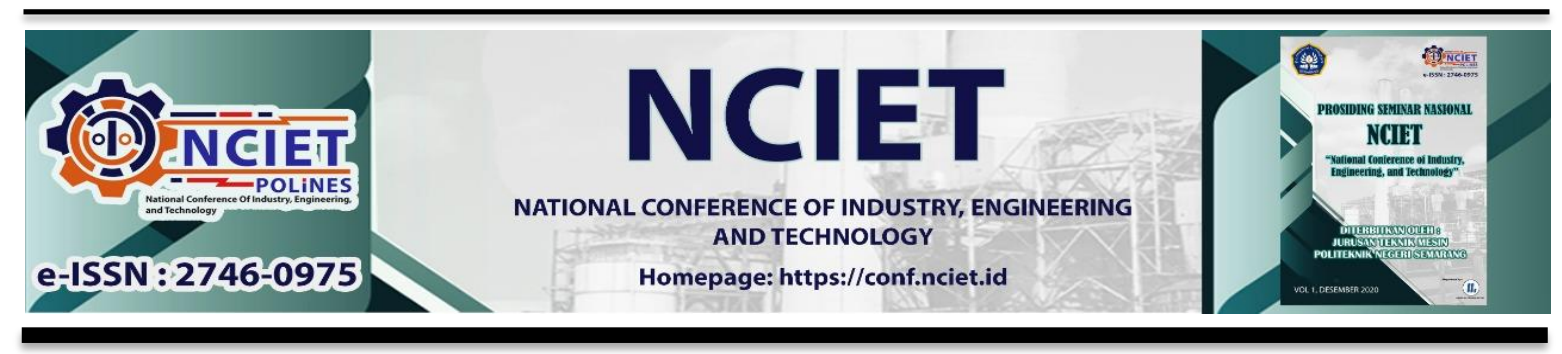

Prosiding Seminar Nasional NCIET Vol.1 (2020) B48-B58

$1^{\text {st }}$ National Conference of Industry, Engineering and Technology 2020,

Semarang, Indonesia.

\title{
PEMILIHAN BATUBARA KALIMANTAN UNTUK PLTU DENGAN PC BOILER MENGGUNAKAN TINJAUAN POTENSI SLAGGING DAN FOULING
}

\author{
Hariana*, Hanafi Prida Putra, Fairuz Milkiy Kuswa \\ Balai Teknologi Bahan Bakar dan Rekayasa Desain, Badan Pengkajian dan Penerapan \\ Teknologi \\ Gedung 480, Kawasan Puspiptek, Tangerang Selatan, 15314 \\ *E-mail: hariana@bppt.go.id
}

\begin{abstract}
Abstrak
Pembangkit listrik tenaga uap (PLTU) merupakan sektor penting energi nasional. PLTU di Indonesia menggunakan batubara peringkat rendah dan menengah sebagai bahan bakar. Syarat utama batubara yang digunakan adalah nilai kalor, selain itu indikasi slagging dan fouling juga diperlukan untuk menjaga efisiensi boiler dan mencegah masalah saat pengoperasian PLTU. Sebelum diumpankan ke boiler PLTU diperlukan pengujian untuk mengetahui potensi slagging dan fouling dari batubara tersebut. drop tube furnace (DTF) dapat digunakan sebagai subtitusi pulverized coal boiler ( $\mathrm{PC}$ boiler) untuk uji bakar dan melihat indikasi slagging dan fouling dari batubara. Untuk menentukan potensi slagging dan fouling dari batubara digunakan perhitungan prediksi slagging dan fouling dari hasil karakteristik batubara, observasi probe hasil uji bakar, analisis SEM morfologi dan EDX, dan analisis XRD. Dari kelima sampel batubara dari Kalimantan yang digunakan pada penelitian ini, sampel batubara KTG1 merupakan batubara dengan potensi slagging dan fouling paling rendah dan dapat direkomendasikan sebagai bahan bakar tunggal untuk boiler PLTU demikian juga untuk KTM1. Sementara sampel batubara lain dapat direkomendasikan untuk digunakan sebagai bahan bakar dengan mencampur batubara lain.
\end{abstract}

Kata Kunci: batubara; slagging; fouling; drop tube furnace; PLTU

\section{PENDAHULUAN}

Indonesia merupakan negara dengan pertumbuhan ekonomi yang tergolong tinggi sehingga untuk menopang pertumbuan tersebut diperlukan kecukupan energi listrik, sebagai mana sesuai data BPS diawal 2020 yang masih bertumbuh 3-8\% di semua sektor. Untuk pemenuhan kebutuhan tersebut, pembangkit listrik di Indonesia sebagian besar menggunakan bahan bakar fosil terutama batubara yang menyumbang sekitar $60 \%$ (Arinaldo \& Adiatma, 2019), sehingga pembangkit listrik jenis ini merupakan salah satu sektor penting energi nasional.

Sementara itu porsi batubara Indonesia didominasi oleh batubara peringkat rendah (nilai kalori di bawah $5100 \mathrm{kkal} / \mathrm{kg}$ ) dan batubara peringkat menengah (nilai kalori pada kisaran 
5100-6100 kkal/kg). Pada tahun 2019, sumber daya batubara untuk batubara peringkat rendah sekitar 36,02\% dan batubara peringkat menengah sekitar 53,62\%, sedangkan cadangan batubara untuk batubara peringkat rendah sekitar 38,45\% dan batubara peringkat menengah sekitar 54,11\% (Pusat Sumber Daya Mineral Batubara dan Panas Bumi, 2020). Oleh karena itu, PLTU di Indonesia menggunakan batubara peringkat rendah dan batubara peringkat menengah sebagai bahan bakarnya.

Salah satu syarat PLTU batubara dapat beroperasi dengan handal dan efisien tinggi adalah terbebas dari masalah slagging dan fouling, dimana peran batubara adalah sangat penting dalam menyumbang potensi terjadinya slagging dan fouling (Hare et al. 2010). Beberapa PLTU sering mengalami masalah pada operasional boiler karena penggunaan batubara jenis tertentu, walaupun batubara tersebut memiliki nilai kalor yang relatif tinggi (Wall et al., 1993). Untuk menghindari masalah ini batubara harus ditinjau dari potensi slagging dan fouling dengan melakukan serangkaian uji coba dalam skala pilot untuk mengetahui potensi slagging dan fouling dari batubara. Salah satu cara pengujian untuk mengetahui indikasi slagging dan fouling adalah menggunakan peralatan drop tube furnace (DTF). DTF dianggap mewakili pulverized coal boiler (PC Boiler) karena suhu tungku dan sekitarnya dapat dikondisikan sama atau mirip dengan PC Boiler (Jiang et al., 1999; Li et al., 2015; Wei, 2016).

Pada penelitian ini dibahas mengenai pemilihan batubara dari berbagai tambang di Kalimantan untuk memenuhi kebutuhan PLTU yang menggunakan PC Boiler. Pemilihan ini berdasarkan analisis potensi slagging dan fouling dari batubara dan analisis hasil uji bakar menggunakan DTF dengan kelengkapan dan tahapannya. Hasil dari pengujian ini adalah urutan rekomendasi dari pemilihan kelima batubara dan potensi solusi alternatif jika ternyata berpotensi slagging dan fouling. Solusi alternatif tersebut diantaranya blending, mineral aditif, shootblower, atau kimia aditif (Hare et al., 2010).

\section{METODE PENELITIAN}

Pada penelitian ini digunakan lima sampel batubara yang berasal dari berbagai tambang di Kalimantan yaitu KTM1, KTM2, KTM3, KTM4, dan KTG1. Pengujian karakteristik laboratorium difokuskan pada kandungan sulfur, ash fusion temperature, dan analisis komposisi abu. Dari hasil pengujian karakteristik ini dihitung prediksi slagging dan fouling berdasarkan analisa abu tersebut dengan rumusan sederhana yang biasanya dipakai seperti,

Rasio basa asam (Babcock and Wilcox, 2005) 


$$
\frac{B}{A}=\frac{\mathrm{Fe}_{2} \mathrm{O}_{3}+\mathrm{CaO}+\mathrm{MgO}+\mathrm{Na}_{2} \mathrm{O}+\mathrm{K}_{2} \mathrm{O}}{\mathrm{SiO}_{2}+\mathrm{AI}_{2} \mathrm{O}_{3}+\mathrm{TiO}_{2}}
$$

Indeks slagging (Babcock and Wilcox, 2005)

$$
R_{S}=\frac{B}{A} \cdot S
$$

Rasio silika (Raask, 1985)

$$
\mathrm{Si}_{R}=\frac{\mathrm{SiO}_{2}}{\mathrm{SiO}_{2}+\mathrm{Fe}_{2} \mathrm{O}_{3}+\mathrm{CaO}+\mathrm{MgO}} \cdot 100
$$

Fusibilitas (Babcock and Wilcox, 2005)

$$
T_{A F I}=\frac{4 I T+H T}{5}
$$

Indeks fouling (Babcock and Wilcox, 2005)

$$
R_{f}=\frac{B}{A} \cdot\left(\mathrm{Na}_{2} \mathrm{O}\right)
$$

Tahapan berikutnya adalah uji pembakaran pada peralatan Drop Tube Furnace (DTF) yang dioperasikan pada suhu $1175^{\circ} \mathrm{C}$ dengan oksigen berlebih sebanyak 5\%. Pada saat uji pembakaran, diambil sampel dengan panel probe yang dimasukkan ke tungku pada area bersuhu $550^{\circ} \mathrm{C}$ dan $600^{\circ} \mathrm{C}$ selama 1 jam. Hasil abu yang menempel di probe kemudian diobservasi, diambil abunya, dan dibandingkan dengan tabel klasifikasi abu (López et al., 2003). Abu yang diambil kemudian diamati lebih dalam dengan scanning electron microscope (SEM) JEOL JSM 6510-LA dilengkapi MOXTEL 550i thin film coated IXRF dispersive energy spectrometer dan dianalisis dengan $x$-ray diffraction (XRD) menggunakan Empyrean type bragg-brentano diffractometer dari Panalytical. Selanjutnya dari perhitungan prediksi, observasi probe, analisis SEM morfologi EDX, dan analisis XRD diambil kesimpulan mengenai kelayakan batubara tersebut.

\section{Prediksi Slagging dan Fouling}

\begin{tabular}{|c|c|c|c|c|c|c|c|}
\hline \multicolumn{3}{|c|}{ PARAMETER } & \multirow{2}{*}{$\begin{array}{c}\text { KTM1 } \\
0.55\end{array}$} & \multirow{2}{*}{$\begin{array}{r}\text { КТМ2 } \\
0.49\end{array}$} & \multirow{2}{*}{$\begin{array}{c}\text { KTM3 } \\
0.31\end{array}$} & \multirow{2}{*}{$\begin{array}{c}\text { KTM4 } \\
0.1\end{array}$} & \multirow{2}{*}{$\begin{array}{r}\text { KTG1 } \\
0.25\end{array}$} \\
\hline Total sulphur & $\%$ & $\mathrm{adb}$ & & & & & \\
\hline \multicolumn{8}{|l|}{ AFT Reducing } \\
\hline Deformation & ${ }^{\circ} \mathrm{C}$ & atm & 1120 & 1100 & 1100 & 1240 & 1480 \\
\hline Spherical & ${ }^{\circ} \mathrm{C}$ & atm & 1130 & 1110 & 1110 & 1250 & 1520 \\
\hline Hemisphere & ${ }^{\circ} \mathrm{C}$ & atm & 1180 & 1140 & 1120 & 1260 & 1550 \\
\hline Flow & ${ }^{\circ} \mathrm{C}$ & atm & 1200 & 1160 & 1130 & 1320 & 1560 \\
\hline \multicolumn{8}{|c|}{ AFT Oxidizing } \\
\hline Deformation & ${ }^{\circ} \mathrm{C}$ & atm & 1160 & 1170 & 1130 & 1280 & 1520 \\
\hline Spherical & ${ }^{\circ} \mathrm{C}$ & atm & 1210 & 1200 & 1170 & 1290 & 1560 \\
\hline
\end{tabular}

Hasil pengujian karakteristik batubara di laboratorium dibutuhkan untuk perhitungan prediksi slagging dan fouling. Karkateristik dari kelima sampel batubara dapat dilihat pada Tabel 1.

Tabel 1. Hasil Pengujian Karakteristik Batubara 


\begin{tabular}{|c|c|c|c|c|c|c|c|}
\hline \multicolumn{3}{|c|}{ PARAMETER } & \multirow{2}{*}{$\begin{array}{c}\text { KTM1 } \\
1220\end{array}$} & \multirow{2}{*}{$\begin{array}{r}\text { KTM2 } \\
1220\end{array}$} & \multirow{2}{*}{$\frac{\text { KTM3 }}{1220}$} & \multirow{2}{*}{$\begin{array}{c}\text { KTM4 } \\
1300\end{array}$} & \multirow{2}{*}{$\begin{array}{r}\text { KTG1 } \\
1590\end{array}$} \\
\hline Hemisphere & ${ }^{\circ} \mathrm{C}$ & atm & & & & & \\
\hline Flow & ${ }^{\circ} \mathrm{C}$ & atm & 1240 & 1240 & 1280 & 1360 & 1600 \\
\hline \multicolumn{8}{|l|}{ Ash Analysis } \\
\hline $\mathrm{SiO}_{2}$ & $\%$ & in ash & 46.25 & 49.54 & 44.86 & 35.53 & 63.94 \\
\hline $\mathrm{Al}_{2} \mathrm{O}_{3}$ & $\%$ & in ash & 21.36 & 19.50 & 20.11 & 8.42 & 29.42 \\
\hline $\mathrm{Fe}_{2} \mathrm{O}_{3}$ & $\%$ & in ash & 11.08 & 11.98 & 7.41 & 21.75 & 2.55 \\
\hline $\mathrm{CaO}$ & $\%$ & in ash & 6.06 & 5.22 & 10.58 & 23.05 & 1.14 \\
\hline $\mathrm{MgO}$ & $\%$ & in ash & 4.35 & 3.89 & 2.97 & 9.78 & 0.25 \\
\hline $\mathrm{TiO}_{2}$ & $\%$ & in ash & 0.82 & 0.65 & 0.66 & 0.34 & 1.82 \\
\hline $\mathrm{Na}_{2} \mathrm{O}$ & $\%$ & in ash & 1.42 & 0.52 & 4.63 & 0.07 & 0.07 \\
\hline $\mathrm{K}_{2} \mathrm{O}$ & $\%$ & in ash & 1.10 & 1.55 & 1.14 & 0.36 & 1.14 \\
\hline $\mathrm{Mn}_{3} \mathrm{O}_{4}$ & $\%$ & in ash & 0.117 & 0.181 & 0.035 & 0.27 & 0.01 \\
\hline $\mathrm{P}_{2} \mathrm{O}_{5}$ & $\%$ & in ash & 0.309 & 0.293 & 0.446 & 0.092 & 0.157 \\
\hline $\mathrm{SO}_{3}$ & $\%$ & in ash & 6.91 & 6.48 & 6.98 & 0.22 & 0.28 \\
\hline
\end{tabular}

Batubara dengan jenis abu bituminous memiliki parameter utama untuk indikasi slagging adalah indeks slagging dan untuk indikasi fouling adalah indeks fouling. Sementara untuk batubara dengan jenis abu lignitic, parameter utama untuk indikasi slagging adalah fusibilitas dan untuk indikasi fouling adalah kandungan $\mathrm{Na}_{2} \mathrm{O}$ pada abu. Untuk menentukan jenis abu dapat digunakan perhitungan perbandingan abu $\mathrm{Fe}_{2} \mathrm{O}_{3}$ dengan $\mathrm{CaO}$ dan $\mathrm{MgO}$ (Babcock and Wilcox, 2005).

Tabel 2. Jenis Abu Batubara

\begin{tabular}{cc}
\hline Sampel Batubara & Jenis Abu Batubara \\
\hline KTM1 & Bituminous \\
KTM2 & Bituminous \\
KTM3 & Lignitic \\
KTM4 & Lignitic \\
KTG1 & Bituminous \\
\hline
\end{tabular}

Perhitungan sederhana prediksi slagging dan fouling dilakukan dengan data dari Tabel 1 sehingga diperoleh hasil pada Tabel 3 berikut. Nilai-nilai dari Tabel 3 kemudian dibandingkan dengan masing-masing kriteria resiko dari referensi.

Tabel 3. Prediksi Slagging dan Fouling Berdasarkan Analisis Abu

\begin{tabular}{lrrrrrr}
\hline Parameter & KTM1 & KTM2 & KTM3 & KTM4 & KTG1 & Referensi \\
\hline Indikasi Slagging & & & & & & \\
Rasio B/A & 0,35 & 0,33 & 0,41 & 1,24 & 0,05 & B\&W (2005) \\
Rasio Silika & 68,27 & 70,14 & 68,16 & 39,43 & 94,20 & Raask (1985) \\
Indeks Slagging & 0,19 & 0,16 & 0,13 & 0,12 & 0,01 & B\&W (2005) \\
Fusibilitas & 1140 & 1124 & 1124 & 1252 & 1502 & B\&W (2005)
\end{tabular}




\begin{tabular}{|c|c|c|c|c|c|c|}
\hline Parameter & KTM1 & KTM2 & KTM3 & KTM4 & KTG1 & Referensi \\
\hline Besi/Kalsium & 1,83 & 2,30 & 0,70 & 0,94 & 2,24 & Bryers (1996) \\
\hline Besi & 11,08 & 11,98 & 7,41 & 21,75 & 2,55 & Raask (1985) \\
\hline Besi + Kalsium & 17,15 & 17,20 & 17,99 & 44,80 & 3,69 & Plaza (2014) \\
\hline \multicolumn{7}{|l|}{ Indikasi Fouling } \\
\hline Indeks Fouling & 0,4965 & 0,1728 & & & 0,0038 & B\&W (2005) \\
\hline $\mathrm{Na}_{2} \mathrm{O}$ pada abu & & & 4,63 & 0,07 & & $\mathrm{~B} \& \mathrm{~W}(2005)$ \\
\hline \multicolumn{7}{|l|}{ Kriteria resiko: } \\
\hline Rendah & Sedang & & Tinggi & & $\mathrm{Pa}$ & \\
\hline
\end{tabular}

Berdasarkan Babcock and Wilcox (2005), prediksi slagging untuk batubara dengan abu bituminous adalah berdasarkan slagging indeks yang besarnya tergantung rasio B/A dan total sulfur dried basis free ash, sedangkan abu jenis liginite berdasarkan fusibilitas. Dengan demikian, sampel batubara KTM1, KTM2 dan KTG1 berpotensi slagging rendah, sedangkan KTM3 berpotensi slagging tinggi hingga parah dan KTM4 berpotensi slagging sedang. Untuk parameter lain terkait slagging dalam praktek bisnis di Indonesia adalah sebagai pelengkap untuk mendukung kedua data tersebut.

Berdasarkan kriteria resiko fouling oleh Babcock \& Wilcox (2005), sampel batubara KTM2 dan KTG1 yang merupakan batubara abu bituminous memiliki potensi fouling yang rendah dapat dilihat dari nilai indeks fouling yang di bawah nilai 0,2 . Sementara sampel batubara KTM1 memiliki potensi fouling sedang karena memiliki nilai indeks fouling di antara 0,2 0,5. Sampel batubara KTM3 dan KTM4 merupakan batubara abu lignitic dengan kandungan abu $\mathrm{Fe}_{2} \mathrm{O}_{3}, \mathrm{CaO}$, dan $\mathrm{MgO}$ di atas 20\%. KTM3 memiliki potensi fouling tinggi karena kandungan $\mathrm{Na}_{2} \mathrm{O}$ di atas $3 \%$, sementara KTM4 memiliki potensi fouling rendah karena kandungan $\mathrm{Na}_{2} \mathrm{O}$ di bawah $3 \%$.

\section{Pengamatan Probe Hasil DTF}

Gambar 1 menunjukkan probe hasil pengambilan sampel dari tungku saat uji pembakaran. Sampel diambil dari area tungku bersuhu $550^{\circ} \mathrm{C}$ yang diasumsikan mewakili daerah economizer atau wall tube pada boiler (fouling) dan suhu $600^{\circ} \mathrm{C}$ yang diasumsikan mewakili daerah super heater (slagging). Di masing-masing probe suhu, gambar kiri menunjukkan probe sampel yang keluar dari tungku, sementara gambar kanan menunjukkan probe sampel yang telah diambil abunya.

Probe sampel suhu $550^{\circ} \mathrm{C}$ yang mewakili pengamatan fouling untuk KTM1, KTM2, KTM3, dan KTM4 setelah dilakukan pengambilan abu masih terdapat debu dan sintering ringan yang tidak dapat diambil sehingga jika dibandingkan dengan tabel klasifikasi abu dari Lopez (2003) masuk skala 1 menuju 2 dari skala 10, semakin tinggi skala semakin 
buruk potensi slagging atau foulingnya. Sementara untuk KTG1 setelah dilakukan pengambilan abu probe terlihat sangat bersih sehingga masuk ke skala 0 .

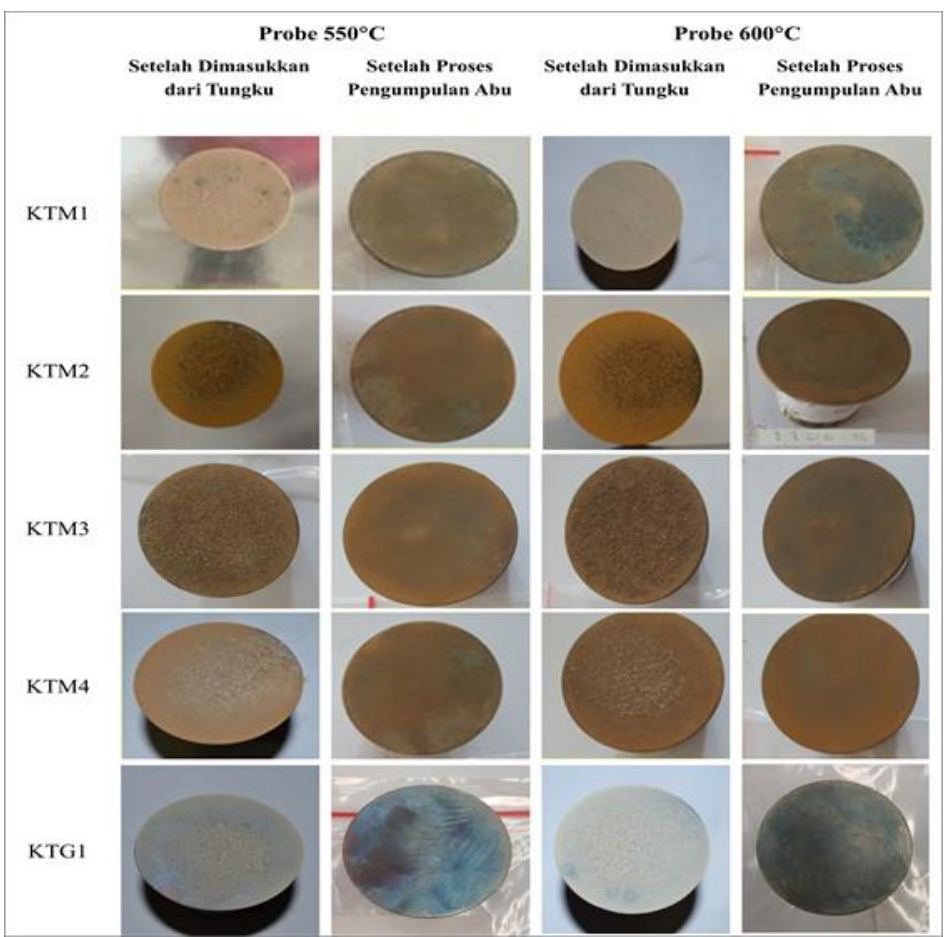

Gambar 1. Probe Sampel Setelah Uji Bakar dan Setelah Pengambilan Abu Probe sampel suhu $600^{\circ} \mathrm{C}$ yang mewakili pengamatan slagging untuk KTM1 setelah dilakukan pengambilan abu masih terdapat sintering yang ringan sehinga masuk ke skala 1 . KTM2, KTM3, dan KTM4 masuk skAla 1 menuju 2, sementara KTG1 masuk skala 0 menuju 1.

\section{Pengamatan SEM Morfologi dan EDX}

Ada beberapa macam jenis morfologi material debu dan slagging yang menempel pada boiler PLTU yaitu metallic, amorphous, vesicular dan sintered (Hatt, 1990). Hal yang serupa tentang klasifikasi deposit juga dikemukakan oleh Laursen (1998) bahwa material slagging berupa porous deposits, powder deposits, iron-rich deposits, semi-fused slags, dan fused slags.

Pengamatan hasil pemotretan SEM pada pengambilan abu suhu $550^{\circ} \mathrm{C}$ dari $\mathrm{KTM} 1$ dapat dilihat bentuk materialnya berupa serpihan, granul, dan porous dengan ukuran bervariasi dari 5 - 25 mikron. Dari hasil analisis EDX menunjukkan bahwa terdapat kandungan logam yang berpengaruh ke potensi slagging yaitu Fe yang tinggi, sedikit K, dan sedikit $\mathrm{Ca}$. Fe ini membentuk $\mathrm{Fe}_{2} \mathrm{O}_{3}$ yang dimana elemen ini mulai bertransformasi pada suhu $590^{\circ} \mathrm{C}$ dan mencair sempurna pada suhu $1500^{\circ} \mathrm{C}$ dan mengikat unsur lain, sementara elemen yang mengandung $\mathrm{K}$ akan meleleh pada suhu rendah. Jika $\mathrm{Fe}_{2} \mathrm{O}_{3}$ dan $\mathrm{K}$ bereaksi membentuk 
Potassium iron oxide maka akan membuat Si dan Al menempel dan menyebabkan lelehan pada suhu rendah (Bryer, 1996). Sementara itu logam $\mathrm{Ca}$ terikat dengan $\mathrm{SO}_{2}$ membentuk $\mathrm{CaSO}_{4}$, elemen ini mencair pada suhu $1000^{\circ} \mathrm{C}$ dan $\mathrm{SO}_{4}$ akan terlepas kemudian bereaksi dengan elemen lain seperti Si dan $\mathrm{Al}$ membentuk lelehan $\mathrm{Ca}_{2} \mathrm{AlSiO}_{7}$ (Qi et al., 2017). Untuk abu suhu $600^{\circ} \mathrm{C}$ dari $\mathrm{KTM} 1$ terdapat material berupa serpihan, granul, dan porous dengan ukuran bervariasi dari 5 - 10 mikron. Dari hasil analisis EDX perlu diperhatikan karena adanya logam $\mathrm{Fe}, \mathrm{K}$, dan $\mathrm{Ca}$.

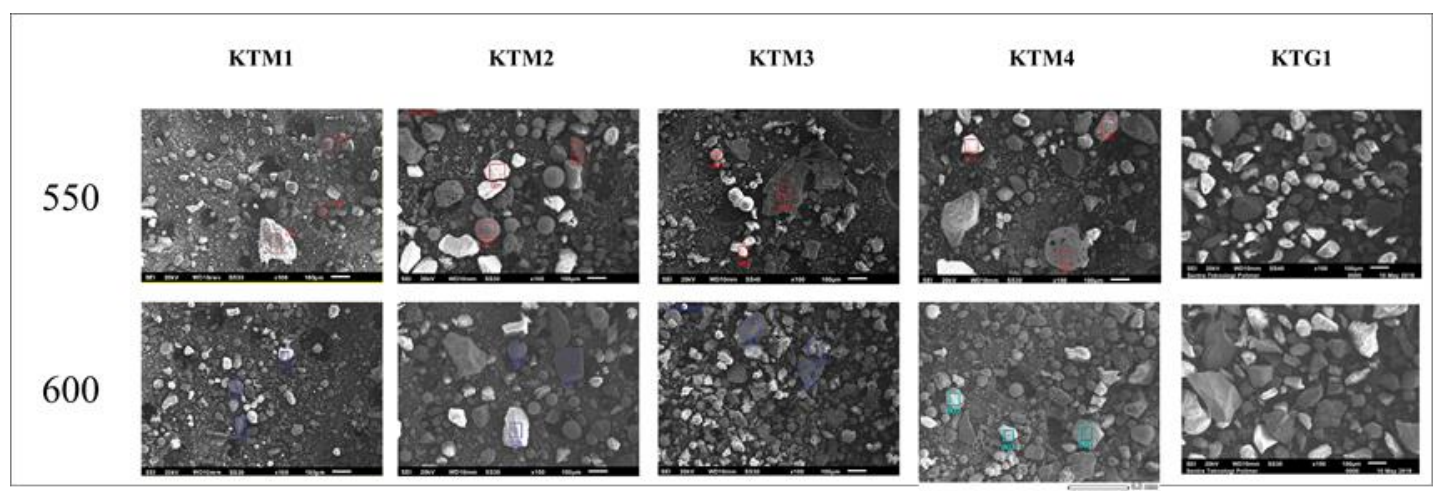

Gambar 2. Potret SEM dari Abu Sampel Batubara Suhu $550^{\circ} \mathrm{C}$ dan $600^{\circ} \mathrm{C}$

Tabel 4. Hasil Analisis EDX dari Abu Sampel Batubara Suhu $550^{\circ} \mathrm{C}$ dan $600^{\circ} \mathrm{C}$

\begin{tabular}{crrrrrrrrrr}
\hline \multirow{2}{*}{ Elemen } & \multicolumn{3}{c}{ KTM1 } & \multicolumn{2}{c}{ KTM2 } & \multicolumn{2}{c}{ KTM3 } & \multicolumn{2}{c}{ KTM4 } & \multicolumn{2}{c}{ KTG1 } \\
& 550 & 600 & 550 & 600 & 550 & 600 & 550 & 600 & 550 & 600 \\
\hline $\mathrm{C}$ & 4.36 & 9.67 & 8.29 & 8.29 & 4.02 & 6.35 & 6.05 & 6.65 & 0.00 & 2.41 \\
$\mathrm{O}$ & 46.49 & 44.29 & 41.80 & 41.80 & 44.63 & 45.57 & 39.67 & 45.88 & 49.88 & 47.43 \\
$\mathrm{Mg}$ & 0.89 & 0.89 & 0.42 & 0.00 & 2.10 & 1.43 & 0.81 & 0.31 & 0.00 & 0.00 \\
$\mathrm{Al}$ & 10.85 & 17.41 & 4.86 & 4.86 & 9.52 & 11.66 & 6.13 & 14.88 & 16.60 & 1.02 \\
$\mathrm{Si}$ & 21.76 & 21.65 & 23.89 & 23.89 & 10.33 & 13.70 & 19.11 & 22.71 & 33.31 & 49.14 \\
$\mathrm{Ti}$ & 0.21 & 0.69 & 0.00 & 0.00 & 0.68 & 0.00 & 0.12 & 0.53 & 0.22 & 0.00 \\
$\mathrm{Fe}$ & 13.59 & 2.57 & 15.92 & 15.92 & 6.92 & 3.82 & 25.45 & 2.58 & 0.00 & 0.00 \\
$\mathrm{~K}$ & 1.35 & 1.54 & 3.00 & 0.00 & 0.28 & 1.29 & 0.70 & 3.54 & 0.00 & 0.00 \\
$\mathrm{Ca}$ & 0.20 & 0.47 & 0.60 & 0.60 & 12.96 & 6.68 & 1.00 & 1.38 & 0.00 & 0.00 \\
$\mathrm{~S}$ & 0.00 & 0.00 & 0.33 & 0.00 & 2.79 & 3.73 & 0.67 & 0.34 & 0.00 & 0.00 \\
$\mathrm{Na}$ & 0.00 & 0.00 & 0.61 & 0.00 & 0.00 & 5.29 & 0.29 & 0.31 & 0.00 & 0.00 \\
$\mathrm{P}$ & 0.00 & 0.00 & 0.00 & 0.00 & 0.00 & 0.73 & 0.00 & 0.00 & 0.00 & 0.00 \\
\hline
\end{tabular}

Pengamatan KTM2 untuk abu suhu $550^{\circ} \mathrm{C}$ dan $600^{\circ} \mathrm{C}$ menunjukkan material didominasi dengan bentuk porous dan bola bola berwarna abu-abu yang tinggi Fe dengan ukuran 5-25 mikron. Terdapat juga beberapa lelehan yang mulai terbentuk. Dari analisis EDX juga menunjukkan bahwa abu dari KTM2 memiliki Fe yang cukup tinggi, sedikit Ca, dan untuk abu suhu $550^{\circ} \mathrm{C}$ terdapat tinggi $\mathrm{K}$. Pengamatan KTM3 untuk abu suhu $550^{\circ} \mathrm{C}$ dan $600^{\circ} \mathrm{C}$ menunjukkan material didominasi dengan bentuk serpihan, lelehan kering, dan bola-bola dengan ukuran 5-50 mikron. Dari hasil analisis EDX perlu diperhatikan dari kedua abu 
sampel adalah kandungan Ca yang tinggi, adanya $\mathrm{S}$, sedikit $\mathrm{K}$, dan $\mathrm{Na}$ yang tinggi di abu suhu $600^{\circ} \mathrm{C}$. Na merupakan logam yang mudah meleleh jika dibandingkan $\mathrm{Fe}$ dan $\mathrm{K}$. Pengamatan KTM4 untuk abu suhu $550^{\circ} \mathrm{C}$ dan $600^{\circ} \mathrm{C}$ menunjukkan adanya serpihan, amorf, dan bola berongga dengan ukuran 20-30 mikron. Dari hasil analisis EDX perlu diperhatikan dari kedua abu sampel adalah kandungan Fe yang sangat tinggi pada abu suhu $550^{\circ} \mathrm{C}$, sedikit $\mathrm{Ca}$, adanya S, K yang tinggi pada abu suhu $600^{\circ} \mathrm{C}$, dan sedikit Na. Pengamatan KTG1 untuk abu suhu $550^{\circ} \mathrm{C}$ dan $600^{\circ} \mathrm{C}$ menunjukkan granul solid tanpa lelehan dengan ukuran $5-10$ mikron. Dari hasil EDX didominasi oleh Si dan Al serta sedikit Ti tanpa adanya logam yang berpotensi menyebabkan terjadinya slagging.

\section{Analisis XRD}

Analisis XRD untuk abu suhu $550^{\circ} \mathrm{C}$ dari $\mathrm{KTM} 1$ didominasi oleh quartz $\left(\mathrm{SiO}_{2}\right)$ sebanyak $84 \%$, sementara itu kandungan lain adalah anhydrite $\left(\mathrm{CaSO}_{4}\right) 9 \%$ dan hematite $\left(\mathrm{Fe}_{2} \mathrm{O}_{3}\right) 7 \%$. Quartz adalah senyawa yang tidak berbahaya dalam potensi slagging. Unsur ini akan stabil sampai suhu $570^{\circ} \mathrm{C}$ dan kemudian akan bertransformasi menjadi high quartz. Pada suhu $867^{\circ} \mathrm{C}$ bertransformasi menjadi tridymite dan selanjutnya pada suhu $1400^{\circ} \mathrm{C}$ akan bertransformasi menjadi cristobalite. Masalah untuk quartz adalah jika ada unsur lain yang lebih dahulu meleleh dan mengikat quartz dan dipanaskan terus menerus maka akan terbentuk gumpalan (Bryer, 1996; Reifenstein et al., 1999). Sementara itu seperti penjelasan pada analisis SEM, $\mathrm{CaSO}_{4}$ dan $\mathrm{Fe}_{2} \mathrm{O}_{3}$ dapat berpengaruh ke potensi slagging. Untuk abu suhu $600^{\circ} \mathrm{C}$ dari $\mathrm{KTM} 1$ didominasi oleh quartz sebanyak 84\%, sementara itu kandungan lain adalah anhydrite $6 \%$ dan hematite $10 \%$. Untuk $\mathrm{KTM} 2$ abu suhu $550^{\circ} \mathrm{C}$ didominasi quartz $98 \%$ dengan sisanya adalah potassium iron oxide $\left(\mathrm{K}_{3}\left(\mathrm{FeO}_{2}\right)\right) 2 \%$ sehingga potensi fouling rendah. Untuk abu suhu $600^{\circ} \mathrm{C}$ didominasi oleh quartz $62 \%$ dan sillimanite $\left(\mathrm{Al}_{2} \mathrm{SiO}_{5}\right)$ $38 \%$, kedua senyawa tersebut tidak berbahaya dalam potensi slagging. Untuk KTM3 abu suhu $550^{\circ} \mathrm{C}$ didominasi quartz $63 \%$, selanjutnya anhydrite $19 \%$, hematite $9 \%$, dan sulfur oksida 9\%. Dari hasil ini dapat dilihat bahwa hematite belum bereaksi dengan elemen lain, tetapi dengan adanya sulfur oksida perlu diwaspadai. Untuk abu suhu $600^{\circ} \mathrm{C}$ didominasi oleh anhydrite $51 \%$, quartz $43 \%$, dan hematite 6\%. Kandungan anhydrite yang tinggi perlu diwaspadai. Untuk KTM4 abu suhu $550^{\circ} \mathrm{C}$ didominasi quartz $68 \%$, selanjutnya anhydrite $17 \%$, dan hematite $16 \%$. Untuk abu suhu $600^{\circ} \mathrm{C}$ didominasi oleh didominasi quartz $71 \%$, selanjutnya anhydrite $22 \%$, dan hematite $8 \%$. Untuk KTG1 abu suhu $600^{\circ} \mathrm{C}$ didominasi oleh didominasi quartz $90 \%$ dan sillimanite $10 \%$. Sementara KTG1 abu suhu $550^{\circ} \mathrm{C}$ tidak dapat 
diuji dan dianalisis dengan XRD karena sampel abu yang menempel di probe terlalu sedikit tetapi dapat dipastikan dari hasil SEM dan perbandingan dengan abu suhu $600^{\circ} \mathrm{C}$ bahwa kandungannya adalah quartz dan sillimanite.

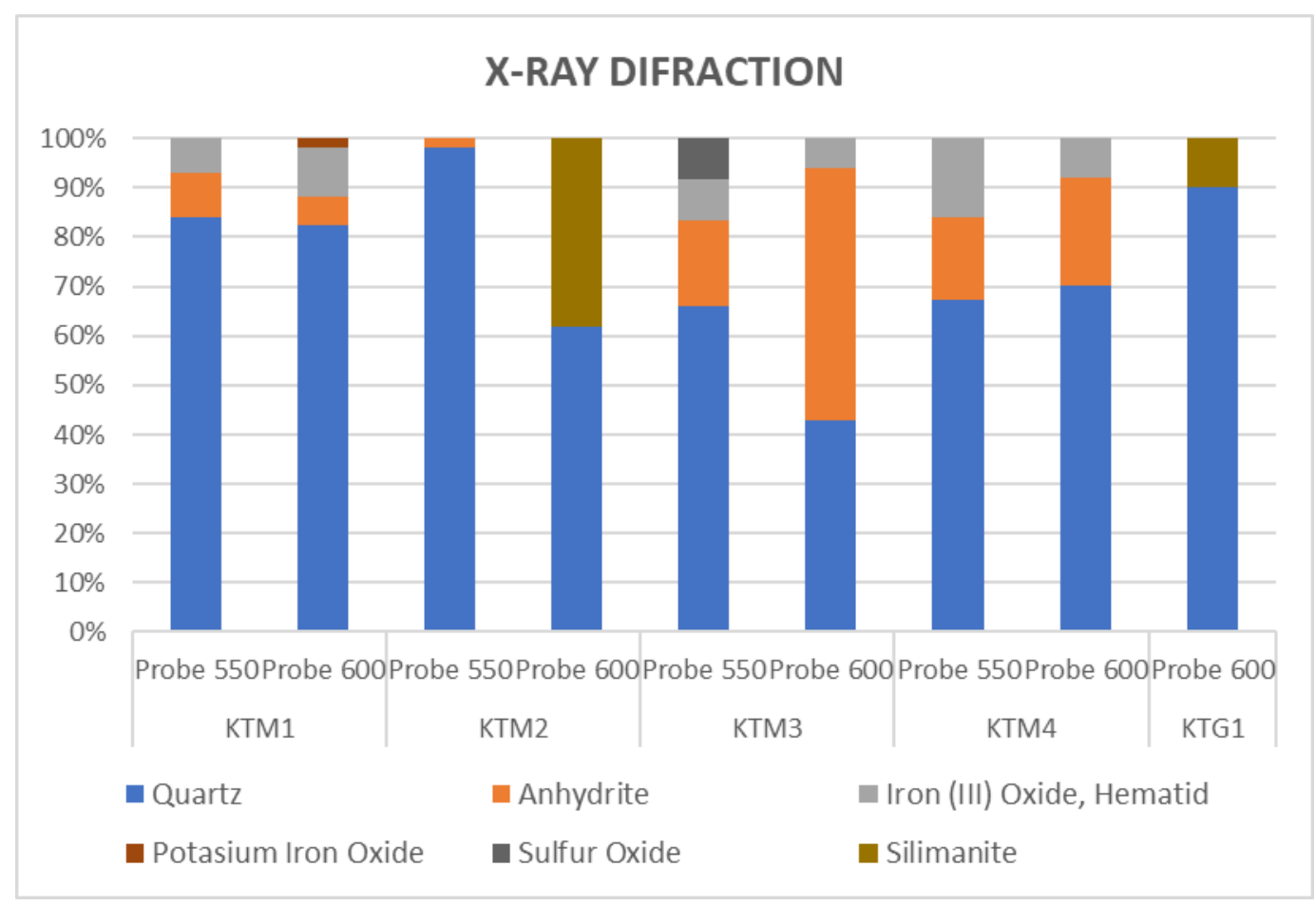

Gambar 3. Diagram Hasil Analisis XRD

Menentukan layak tidaknya batubara digunakan sebagai bahan bakar untuk PLTU berdasarkan potensi slagging dan fouling dapat dilihat dari perhitungan prediksi slagging dan fouling, observasi probe, analisis SEM morfologi dan EDX, dan analisis XRD. Tabel 5 menunjukkan ringkasan dari pembahasan setiap parameter sebelumnya.

Tabel 5. Potensi Slagging dan Fouling dari Sampel Batubara

\begin{tabular}{llllll}
\hline Parameter & KTM1 & KTM2 & KTM3 & KTM4 & KTG1 \\
\hline Prediksi Slagging & Rendah & Rendah & Tinggi & Sedang & Rendah \\
Prediksi Fouling & Sedang & Rendah & Tinggi & Rendah & Rendah \\
Observasi Probe & Sedang & Sedang & Sedang & Sedang & Rendah \\
SEM EDX & Rendah & Sedang & Sedang & Rendah & Rendah \\
XRD & Rendah & Rendah & Sedang & Sedang & Rendah \\
\hline
\end{tabular}

Selanjutnya dari Tabel 5 dianalisis secara kuantitatif menggunakan analisis hierarki proses dengan memberikan nilai 5 pada potensi rendah, 3 untuk sedang, dan 1 untuk tinggi. Selanjutnya dikalikan dengan bobot masing-masing parameter sehingga diperoleh hasil pada Tabel 6. 
KTG1 memiliki indikasi slagging dan fouling paling bagus dengan nilai sempurna 65 . KTM1 dengan nilai 53 perlu diperhatikan dibagian fouling. KTM2 dengan nilai 49 dikarenakan kandungan $\mathrm{Fe}_{2} \mathrm{O}_{3}$ yang tinggi. Kandungan $\mathrm{Fe}_{2} \mathrm{O}_{3}$ dan $\mathrm{CaO}$ yang tinggi juga membuat KTM4 hanya memiliki nilai 47. Sementara itu KTM3 dengan kandungan $\mathrm{CaO}$ dan $\mathrm{Na}_{2} \mathrm{O}$ yang tinggi membuat hasil perhitungan prediksi, analisis SEM morfologi dan EDX, dan analisis XRD pada urutan terakhir 35.

Tabel 6. Potensi Slagging dan Fouling dari Sampel Batubara dalam Bentuk Kuantitatif

\begin{tabular}{lcccccc}
\hline Parameter & KTM1 & KTM2 & KTM3 & KTM4 & KTG1 & Bobot \\
\hline Prediksi Slagging & 5 & 5 & 1 & 3 & 5 & 1 \\
Prediksi Fouling & 3 & 5 & 1 & 5 & 5 & 1 \\
Observasi Probe & 3 & 3 & 3 & 3 & 5 & 5 \\
SEM EDX & 5 & 3 & 3 & 5 & 5 & 3 \\
XRD & 5 & 5 & 3 & 3 & 5 & 3 \\
Total Nilai & 53 & 49 & 35 & 47 & 65 & \\
\hline
\end{tabular}

\section{KESIMPULAN}

Dari kelima sampel yang digunakan untuk penelitian uji pembakaran, sampel batubara KTG1 merupakan sampel dengan potensi slagging dan fouling paling rendah disusul oleh batubara KTM1. Kedua batubara ini dapat dipertimbangkan sebagai batubara tunggal atau sebagai campuran batubara lain untuk bahan bakar PLTU. Ketiga batubara yang lain bisa dipertimbangkan sebagai batubara blending dengan urutan prioritas KTM2, KTM4, dan KTM3. KTM2 memiliki potensi slagging dan fouling rendah ke sedang dan direkomendasikan untuk dicampur dengan batubara yang rendah Fe. KTM4 memiliki potensi slagging dan fouling rendah ke sedang dan direkomendasikan untuk dicampur dengan batubara yang rendah $\mathrm{Fe}$ dan $\mathrm{Ca}$. KTM3 memiliki potensi slagging dan fouling rendah cenderung ke sedang dan direkomendasikan untuk dicampur dengan batubara rendah Ca dan K. Untuk dapat dipertimbangkan sebagai batubara tunggal, KTM2, KTM4, dan KTM3 perlu diteliti lebih lanjut dengan menggunakan mineral aditif yang sesuai atau dengan cara lain.

\section{DAFTAR PUSTAKA}

Arinaldo, D., \& Adiatma, J. C. (2019). Dinamika Batubara Indonesia: Menuju Transisi Energi yang Adil.

Babcock and Wilcox. (2005). Steam Its Generation and Use (5th ed.). McDermott Company. Bryer, R. (1996). Fireside Slagging, Fouling, and High Temperature Corosion of Heat Transfer Surface due to Impurities in Steam Raising Fuel. Progress in Energy and 
Combustion Science, 29-120.

Hare, N., Rasul, M., \& Moazzem, S. (2010). A review on boiler deposition/foulage prevention and removal techniques for power plant.

Hatt, R. M. (1990). Fireside deposits in coal-fired utility boilers. Progress in Energy and Combustion Science, 16(4), 235-241. https://doi.org/https://doi.org/10.1016/03601285(90)90032-X

Jiang, X., Li, J., \& Qiu Jilin (China)], J. [Northeast I. of E. P. E. (1999). The influence of particle size on composition analyzing and combustion characteristics of pulverized coal.

Laursen, K., Frandsen, F., \& Larsen, O. H. (1998). Ash Deposition Trials at Three Power Stations in Denmark. Energy \& Fuels, 12(2), 429-442. https://doi.org/10.1021/ef970106o

Li, G., Li, S., Huang, Q., \& Yao, Q. (2015). Fine particulate formation and ash deposition during pulverized coal combustion of high-sodium lignite in a down-fired furnace. Fuel, 143, 430-437. https://doi.org/https://doi.org/10.1016/j.fuel.2014.11.067

López, C., Unterberger, S., Maier, J., \& Hein, K. R. G. (2003). Overview of actual methods for characterization of ash depostion.

Pusat Sumber Daya Mineral Batubara dan Panas Bumi. (2020). Pemutakhiran Data dan Neraca Sumber Daya Energi Tahun 2020.

Qi, X., Song, G., Song, W., \& Yang, S. (2017). Effect of bed materials on slagging and fouling during Zhundong coal gasification. Energy Exploration \& Exploitation, 35, 014459871770008. https://doi.org/10.1177/0144598717700082

Raask, E. (1985). Mineral impurities in coal combustion: behavior, problems, and remedial measures. Hemisphere Publishing Corporation,Washington, DC. https://www.osti.gov/biblio/5693722

Reifenstein, A. P., Kahraman, H., Coin, C. D. A., Calos, N. J., Miller, G., \& Uwins, P. (1999). Behaviour of selected minerals in an improved ash fusion test: quartz, potassium feldspar, sodium feldspar, kaolinite, illite, calcite, dolomite, siderite, pyrite and apatite. Fuel, 78(12), 1449-1461. https://doi.org/https://doi.org/10.1016/S0016-2361(99)000654

Wall, T. F., Bhattacharya, S. P., Zhang, D. K., Gupta, R. P., \& He, X. (1993). The properties and thermal effects of ash deposits in coal-fired furnaces. Progress in Energy and Combustion Science, 19(6), 487-504. https://doi.org/https://doi.org/10.1016/03601285(93)90002-V

Wei, D. (2016). Investigation on Ash Deposition Characteristics during Zhundong Coal Combustion. Journal of The Energy Institute. 